\title{
Examination of Life Studies Coursebooks in Terms of Inclusive Education ${ }^{1}$
}

DOI: $10.26466 /$ opus.899642

$*$

\author{
Emrullah Akcan * \\ * Assist. Prof., Gaziantep University, Nizip Education Faculty, Gaziantep/Turkey \\ E-Posta: emrullahakcan@gmail.com \\ ORCID: $\underline{0000-0002-5492-4159}$
}

\begin{abstract}
Every individual in a society has unique characteristics and distinctive skills. However, certain individuals exhibit significant differences from others. Inclusive education practices were put into practice by focusing on individuals with special differences. In order for these practices to be successful, especially some materials need to be arranged. In primary schools, the life studies course is one of the most common courses in addition to Turkish and Math in Turkey. Accordingly, the life studies course is placed in an important position. Therefore, it is important to note how compatible Life studies coursebooks are with the inclusion practice. In this study, it was aimed to investigate the life studies coursebooks, which were used in the 2019-2020 education period, in terms of inclusive education practices. For this purpose, three Life studies coursebooks belonging to 1st, 2nd, and 3rd grades of primary school were evaluated by using document analysis, one of the qualitative research methods. Descriptive analysis method was used to analyze the data. According to the descriptive analysis method, the data patterns obtained from the research are analyzed according to the predetermined size or themes. For this reason, the code guide developed by the researcher was used as a data collection tool. As a result of the research, it has been determined that Life studies coursebooks are quite insufficient in terms of inclusion.
\end{abstract}

Key Words: Life Studies, Inclusive Education, Coursebooks.

\footnotetext{
${ }^{1}$ The initial findings of the study were presented at the "18th International Primary Teacher Education Symposium (IPTES 2019)" held in Antalya (Turkey) on 16-20th October 2019.
} 


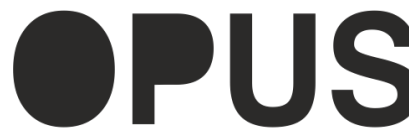

Uluslararası Toplum Araştırmaları Dergisi International Journal of Society Researches
E-ISSN : 2528-9535

YIl Year: 11

Cilt Volume: 18

Sayı Issue :Eğitim Bilimleri Özel Sayısı

Eylül September 2021

Makalenin Gelis Tarihi Received Date: 19/03/2021

Makalenin Kabul Tarihi Accepted Date: 08/05/2021

\section{Hayat Bilgisi Ders Kitaplarının Kaynaştırma Eğitimi Açısından İncelenmesi}

\section{Öz}

Toplumdaki her bireyin kendine özgü farklı özellikleri, yetenekleri vardır. Ancak bazı bireyler, diğgerlerinden önemli derecede farklılık göstermektedir. Kaynaştırma uygulaması, özel farklllkkları olan bireyleri odak noktasına alarak uygulamaya konulmuştur. Bu uygulamanın başarıl olabilmesi için özellikle bazı materyallerin düzenlenmesi gerekmektedir. Bu materyallerin en önemli öğesi ders kitaplarıdır. İlkokulda Türkçe ve Matematik ile birlikte Hayat Bilgisi dersi en sık verilen üç dersten biridir. Bu bağlamda hayat bilgisi dersleri önemli bir yerde konumlandırılmıştır. Dolayısıyla hayat bilgisi kitaplarının kaynaştırma uygulaması ile ne kadar uyumlu olduğu önemli bir husus olarak göze çarpmaktadır. Bu araştırma ile 2019-2020 eğitim öğretim yılında okutulacak olan hayat bilgisi ders kitaplarının kaynaştırma uygulaması açısından incelenmesi amaçlanmıştır. Bu amaç kapsamında ilkokul 1., 2. ve 3. sınıflara ait üç Hayat bilgisi kitabı nitel araştırma yöntemlerinden doküman incelemesi kullanılarak değerlendirilmiştir. Verilerin çözümlenmesinde betimsel analiz yönteminden yararlanılmıştır. Betimsel analiz yöntemine göre araştırmadan elde edilen veri desenleri, daha önceden belirlenen boyut veya temalara göre analiz edilir. Bu sebeple araştırmada veri toplama aracı olarak, araştırmacı tarafından geliştirilen kod rehberi kullanılmıştır. Bu kod rehberi, kaynaştırma ile ilgili göstergelerin bulunduğu başlık ve alt başlıklardan oluşmaktadır. Araştırma sonucunda Hayat bilgisi ders kitaplarının kaynaştırma açısından oldukça yetersiz olduğu tespit edilmiştir.

Anahtar Kelimeler: Hayat Bilgisi, Kapsayıcı Eğitim, Ders kitapları. 


\section{Introduction}

Every individual in a society has unique characteristics and distinctive skills. These differences of individuals are natural and one of the main principles of developmental psychology (Aydın, 2019). However, certain individuals exhibit significant differences from others. It is not easy to be different within a standardized framework for society. Let us empathize and imagine a situation when we are asked to do something that is above our skills and abilities or an emotional situation that is felt due to not having certain things. In such a situation, we even avoid the skills we possess. Thus, individual differences are of great importance.

One of the most prominent problems that affect the education lives of individuals is the unique characteristics of individuals. Each student who started to study in schools deserves an education and educational environment that appeals to themselves and their differences and respect their characteristics regardless of the types and levels of their characteristics. Individual differences, which are brought from birth or acquired later, lead to certain difficulties in school, which is the greatest area for socialization in individuals' lives after the family. This is because the differences among individuals are reflected in their learning characteristics. Thus, it is necessary to implement various types of regulations in education to overcome the difficulties experienced by students who have differences in question. In other words, specialized adaptations are required in educational programs where students cannot internalize information by using their senses, cannot express their feelings, thoughts, requirements, and emotions, and cannot process information in their minds (Kirk, Gallagher and Coleman, 2015). Therefore, certain regulations and implementations were adopted both in Turkey and in the world to enable individuals with special differences to receive an education that is suitable for them. The practice of mainstreaming is implemented by focusing on individuals with special differences (Akcan and İlgar, 2016). The mainstreaming implementation in education aims to achieve inclusive development for students with special needs by including them in the social, cognitive, academic, physical, and other developmental areas within the period they spend with their normal peers in general education classrooms. Today, it can be stated that the concept of 
mainstreaming has left its place to the concept of inclusion. Inclusion, which is the antonym of the concept of exclusion, is a movement of thought that contains differences and variations inside, and consider social models for everyone in terms of human rights and social needs whether the individuals have special inabilities or not. As can be realized from the definition above, the implementations of inclusion do not only focus on the academic development of students but also aim to contribute to other developmental areas, especially to social development.

Inclusive education is a process and this process covers an implementation where numerous constituents, such as teachers, school administrators, special education experts, families, students with normal development, individual educational plans, and counseling research centers, are responsible and play important roles. Among these constituents, classroom teachers, attitudes of students with normal development, and classroom materials are especially important for the implementation to become successful. In the inclusion process, positive attitudes of teachers and students affect achievement directly while certain materials should be regulated and they should be made suitable for all the students in the classroom to facilitate these attitudes.

Numerous studies on inclusive education revealed that the attitudes of teachers and students with normal development toward inclusion directly affected the aimed achievement (Anılan and Kayacan, 2014; Güleryüz and Özdemir, 2015; Gümüş and Tan, 2015; Hwang and Evans, 2011; Y1lmaz and Batu, 2016). Accordingly, it is realized that the attitudes of students play rather important roles. The results of certain studies (Kapucu, Aydoğdu, and Benli, 2020; Karataş and Arslan, 2018; Yazıcıoğlu and Kargın, 2018) determined that the students with normal developments approached their peers with special needs positively while the results of most studies (Schwartz and Armony-Sivan, 2001; Firat and Koyuncu, 2019; Güdük and Y1lmaz, 2019) reported the opposite, determined negative attitudes and that these negative attitudes led to the social rejection of students with special needs. The negative attitudes of students with normal development deeply affect academic achievement, emotional/social adaptation, sympathy toward school, classroom behavior, and self-confidence toward themselves in students (Salend, 1998; as cited by Sucuoğlu, 2006). Therefore, it can be stated that 
the positive and negative attitudes of students with normal development are of vital importance in terms of the success of inclusion practices. These negative attitudes may be due to various reasons. However, it can be stated that the elements with which primary school students, who are rather open to learning, frequently interact, play significant roles in the attitudes of students.

When students enter classrooms, they directly interact with three main elements, teachers, peers, and classroom materials. The most important classroom material is coursebooks. This is because coursebooks are the oldest and most common materials that are used in education. The most important contribution of these materials is that they enable access to information of the course whenever necessary, unlimited times of repetition, and independent study. Furthermore, coursebooks are rather important elements of educational activities in terms of their effects on students, families, and societies at larger scales (Ataman et al., 2001).

In primary schools, the life studies course is one of the most common courses in addition to Turkish and Math in Turkey. Accordingly, the life studies course is placed in an important position. The life studies course is of importance for individuals in terms of viewing the social position of both the students themselves and others (Pamuk and Pamuk, 2016). Considering this point of view, the development of a sense of belonging and increases in social acceptance levels by peers in inclusive students are valuable in terms of developing positive attitudes in students with normal development. This is because the life studies course is one of the first and most important courses for students in terms of recognizing and adopting values, cultures, stereotypes, and thoughts, facilitating the discovery of their societies in every aspect, and raising and supporting awareness (Pamuk and Pamuk, 2016). The life studies course is a door that opens to every field of life (Öztürk and Özkan, 2018). When the course contents of the lesson studies course are examined, it is seen that numerous social values, such as truthfulness, honesty, cooperation, love of nature and humanity, justice, love, and respect, take place in the course (MoNE, 2018). It is known that the course outputs, which cover these values, are brought into the classroom via coursebooks. Topses et al. (2001) stated that life studies coursebooks are the first windows of students, which open to the world and the tools that enable students to 
create and practice the competencies, expectations, and attitudes of students (As cited by Öztürk and Özkan, 2018). When considered within this framework, it can be stated that the covering contents that are related to inclusion in life studies coursebooks can directly affect students' attitudes toward the inclusion of students. Therefore, the importance of the compatibility of life studies courses with inclusive education comes to the forefront.

When the related literature was reviewed, studies that investigated life studies lessons and coursebooks in various aspects (Tural et al., 2017; Erkan, 1998; Erol and Kıroğlu, 2012; Pamuk and Pamuk, 2016; Öztürk and Özkan, 2018; Candan and Ergen, 2014) were observed while studies on inclusive education (Daniel and King, 1997; Sayed and Soudien, 2005; Kibria, 2005; Şahan et al. 2020; Deniz and Çoban, 2019) were also observed. However, no study that investigated life studies coursebooks in terms of inclusion was observed. Thus, this study is regarded as important in terms of setting examples for future studies on this subject in addition to contributing to the literature.

\section{Aim of the Study}

In this study, it was aimed to investigate the life studies coursebooks, which were used in the 2019-2020 education period, in terms of inclusive education practices. Within the framework of this aim, answers to the following questions were sought.

1. How are the images that reflect inclusive students in life studies coursebooks?

2. How are the texts that reflect inclusive students in life studies coursebooks?

\section{Methodology}

In line with the aim of the study, a qualitative study model was adopted and the data were collected by using the document review method. Yıldırım and Şimşek defined document review as an investigation of recorded written/visual materials, which include detailed information about the targeted case or phenomena. Patton (2014) stated that docu- 
ments were rather rich sources of data. The document review method, which is used in qualitative studies, can be a single method of data collection by itself depending on the case or phenomena to be investigated as well as being utilized along with other data collection methods (Yıldırım and Şimşek, 2016). Contrary to methods such as observation, interview, focus-group interview, which include possibilities of mutual interaction, the document review method, which is defined as the analysis of recorded words and/or images without the possibility of any intervention by the researcher, is conducted at 5 main steps (Yıldırım and Şimşek, 2016). These steps cover accessing the documents, authenticating the documents, understanding the documents, analyzing the data, and using the data, respectively.

\section{Data Collection Tools}

The life studies coursebooks, which were investigated within the framework and study and used at the 1st, 2nd, and 3rd grades in official primary schools in the 2019-2020 education period, were chosen as the data sources. These books were chosen by the criterion sampling method, which is one of the purposeful sampling methods and obtained from a randomly-chosen primary school in the city of Gaziantep. The purposeful sampling method enables critical thinking regarding the characteristics of the case that is the subject of research (Silverman, 2018). In the criterion sampling method, which is a type of purposeful sampling, the main notion is to investigate all the cases that meet a series of criteria that are predefined or created by researchers (Yıldırım and Şimşek, 2016). In this way, the possibility to investigate each criterion thoroughly emerges. This is because, according to Patton (2014), the rationale of purposeful sampling and its power is based on their effect on deep meaning. In the light of this information, the eight main subjects of inclusive education (1- Individuals with mental disabilities, 2- Individuals with hearing disabilities, 3- Individuals with visual disabilities, 4- Individuals with physical disabilities, 5- Individuals with speech and language disorders, 6- Individuals with special learning disabilities, 7- Individuals with autism, and 8- Individuals with attention deficiency and hyperactivity (ADHD)) practices were regarded as the criteria and the 
coursebooks in the sample were investigated according to these criteria. The information regarding the coursebooks in the sample was presented in the table below.

Table 1. The coursebooks in the sample

\begin{tabular}{|c|c|c|c|}
\hline Coursebooks & Publisher & Author & Number of Pages \\
\hline $\begin{array}{l}\text { 1st Grade Life Studies Course- } \\
\text { book }\end{array}$ & $\begin{array}{l}\mathrm{Ar}^{* * *} \text { Publish- } \\
\text { ing }\end{array}$ & $\mathrm{Çi}^{* * *} \mathrm{AL}^{* * *}$ & 208 pages \\
\hline $\begin{array}{l}\text { 2nd Grade Life Studies Course- } \\
\text { book }\end{array}$ & $\begin{array}{l}\text { Be }^{* * *} \text { Publish- } \\
\text { ing }\end{array}$ & $\mathrm{Ya}^{* * *} \mathrm{UL}^{* * *}$ & 227 pages \\
\hline $\begin{array}{l}\text { 3rd Grade Life Studies Course- } \\
\text { book }\end{array}$ & $\begin{array}{l}\text { Ev*** Publish- } \\
\text { ing }\end{array}$ & $\mathrm{Er}^{* * *} \mathrm{U}^{* * *} \mathrm{KA}^{* * *}$ & 223 pages \\
\hline
\end{tabular}

\section{Data Analysis}

A form that was developed by the researcher based on the conceptual framework of the study was used as the data collection tool. In this form, the inclusion groups that were stated under 8 main subjects above were included. Each subject was evaluated within two sub-dimension as images and texts. By using the data collection tool that was developed in this study, the life studies coursebooks were examined page by page and the numbers of mentioning inclusive students in each group were recorded as texts and images.

In the analysis of the data, which were collected by the document review method, the descriptive analysis technique was utilized. The descriptive analysis technique consists of four steps, which include a) creating a conceptual framework, b) processing the data according to the framework, c) defining the findings, and d) interpreting the findings. According to this technique, the subject to be investigated is summarized and interpreted according to predefined themes. To support the findings, direct quotations are presented frequently. The data that are obtained are organized in a way that readers can interpret. Then, the data sets are examined according to cause-effect relationships and a series of results are obtained (Yıldırım and Şimşek, 2016).

To keep the validity of the study at acceptable levels, each step of the study, such as data collection, data analysis, data collection tools, sampling, and interpretation of findings, were thoroughly explained. Addi- 
tionally, the findings that are obtained were compared to the findings of similar studies in the literature. To ensure the reliability of the study, the researcher thoroughly examined the data twice between approximately one-year intervals and applied to expert opinions for findings that did not accord. With expert opinions, the final decisions were made. According to Hammersley (1992), reliability is the degree of consistency in the results of the processes conducted by researchers at different times (As cited by Silverman, 2018). In simpler words, it can be stated that if a researcher concludes with the same results, interpretations, and findings by repeating the analysis of the same study, the reliability is ensured.

\section{Findings}

In this section, the images and texts that were detected to reflect inclusion students in life studies coursebooks were presented.

\section{Students with Physical Disabilities}

In general terms, physical disabilities refer to orthopedic differences at a level that restricts individuals' movements. However, the physical disability that is defined in special education cannot be evaluated only in terms of orthopedic differences. Accordingly, physical disabilities refer to individual differences that result from birth or various reasons after birth while individuals with physical disabilities refer to inabilities to perform functions of muscle and skeletal systems and individuals who require special education and supportive educational services due to reasons such as missing or excessive limbs. According to these definitions, the findings that were obtained from the life studies courses of 1st, 2nd, and 3rd grades were presented below.

Images and texts in the 1st grade Life Studies Coursebook: When the 1stgrade life studies coursebook was examined, it was observed that there were only images that reflected inclusion students with physical and hearing disabilities while other inclusion groups were not included. Additionally, all the images that demonstrated physical disabilities only depicted students who used wheelchairs 


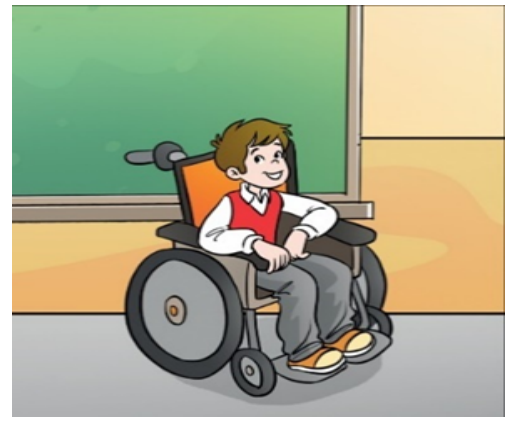

Image 1.

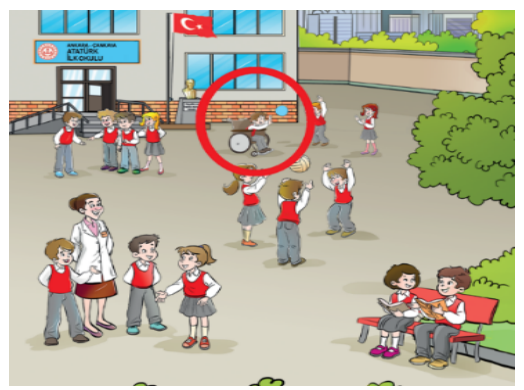

Image 3.

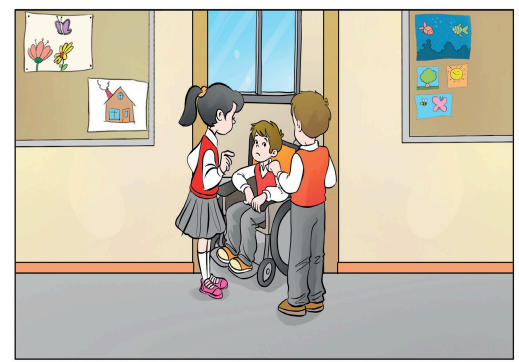

Image 5.

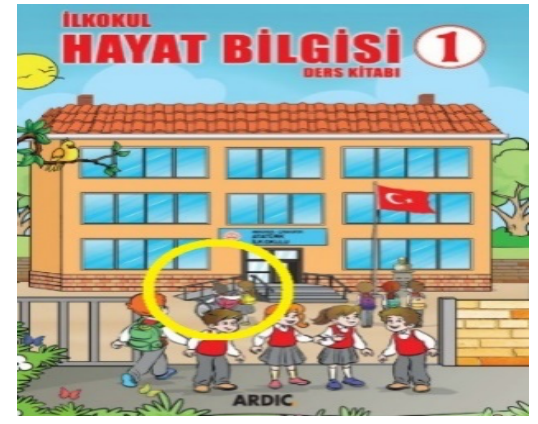

Image 2.

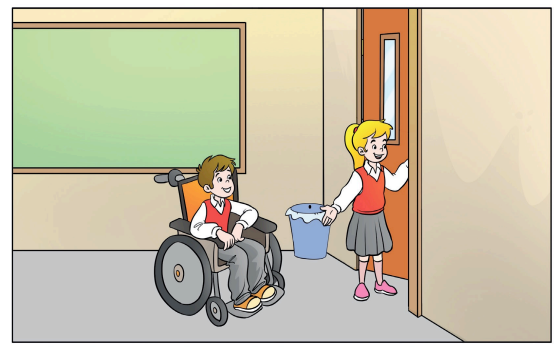

Image 4

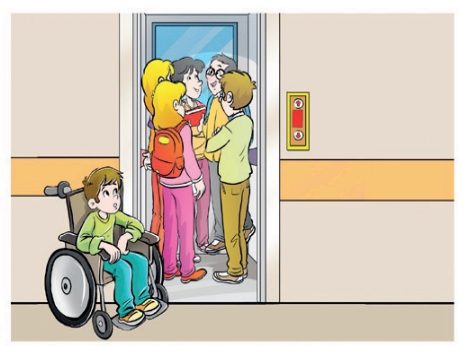

Image 6.

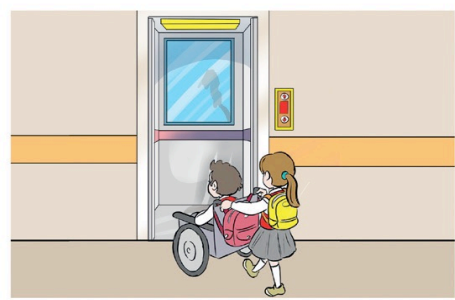

Image 7. 
When the distributions of the images in the coursebook were examined, it was observed that the images were presented in the cover (Image 1), under the themes of Our similar and different aspects (Image 2, Image 4 , and Image 5) and We love school (Image 3), and under the title of where the questions of chapters were located (Image 6 and Image 7).

When the pages of the images were examined, it was observed that the images were located on the cover (Image 1), page 14 (Image 2), page 16 (Image 4 and Image 5), page 46 (Image 3), and page 51 (Image 6 and Image 7). Apart from these images, no images or texts that were related to individuals with physical disabilities were observed in the remaining pages of the book, which was 209 pages long. Similarly, except for the image on the cover, all of the images that reflected inclusion students were located in the first chapter of the book, Life in our school.

When the image-text relationships were evaluated, it was observed that the statement "Hello, I am Efe. I am in the 1/C classroom. I love my school, friends, and teacher very much. I use a wheelchair." was located concerning Image 2 (page 14). On page 16, where Image 4 and Image 5 were located, it was asked to check the correct behavior by comparing both images. The texts that were related to these images included "Examine the images below. In which image is respect to others emphasized? Mark the image that demonstrates the correct behavior". Similar$1 y$, for a situation where it was asked to conduct a comparison, Image 6 and Image 7 were used. On page 51, where the evaluation questions of the chapter were located, it was asked to choose the correct behavior among the three images that were presented in question 5 . The question covered that statement, "In which of the following images is a correct behavior demonstrated? Mark."

Images and texts in the 2nd grade Life Studies Coursebook: When the 2nd-grade life studies coursebook was examined, it was observed that the images that reflected inclusion students with physical disabilities were included more compared to the other inclusion groups. Additionally, all the images demonstrated students who used wheelchairs. 


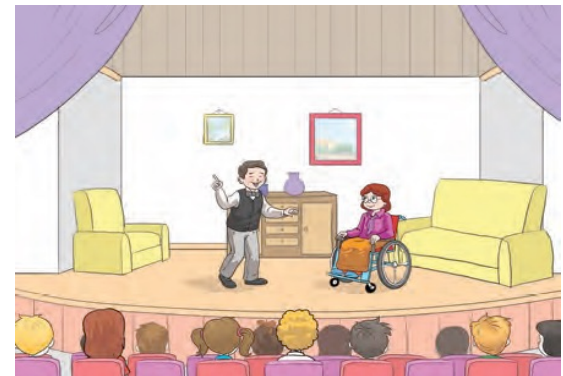

Image 8.

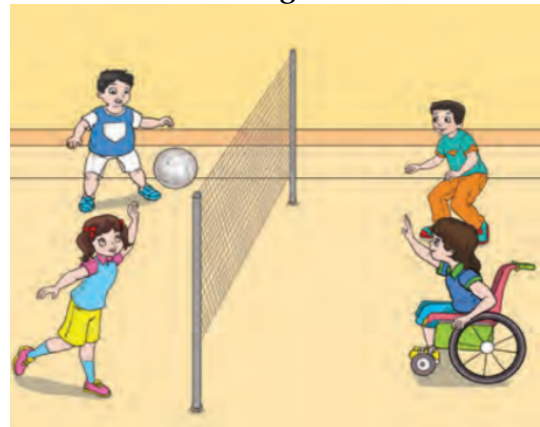

Image 10.

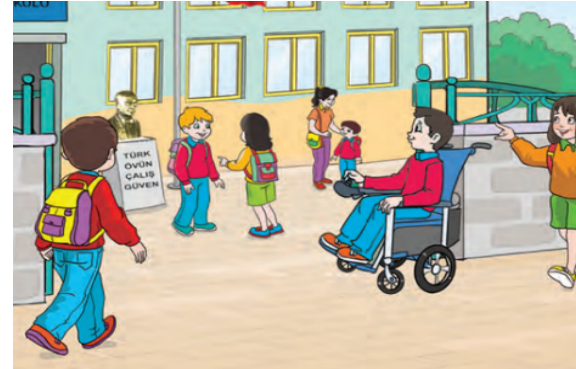

Image 9.

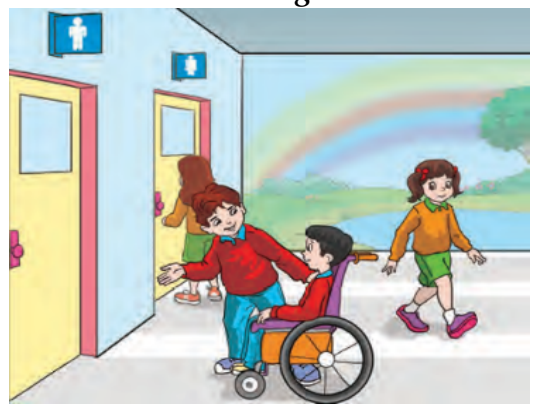

Image 11.

When the distributions of the images in the coursebook were examined, it was observed that the images were presented on the first page of the Life in Our School chapter (Image 8), under the themes of Our Individual Differences (Image 9), Subjects Related to Our Classroom (Image 10), and While Playing Games (Image 11).

When the pages of the images were examined, it was observed that the images were located on page 11 (Image 8), page 21 (Image 9), page 30 (Image 10), and page 52 (Image 11). Apart from these images, no images or texts that were related to students with physical disabilities were observed in the remaining pages of the book, which was 227 pages long. Similarly, all of the images that reflected inclusion students were located in the first chapter of the book, Life in our school.

When the image-text relationships were evaluated, it was observed that the statement "Would you like me to help you?" was located concerning Image 10 (page 30). No texts that were related to the other images and reflected inclusion students were observed. 
Images and texts in the $3^{\text {rd }}$ grade Life Studies Coursebook: When the $3^{\text {rd }}$ grade life studies coursebook was examined, similar to the $1^{\text {st }}$-grade life studies coursebook, it was observed that only the images that reflected inclusion students with physical disabilities were included while no images for the other inclusion groups were presented. Additionally, all the images depicted students who used wheelchairs.

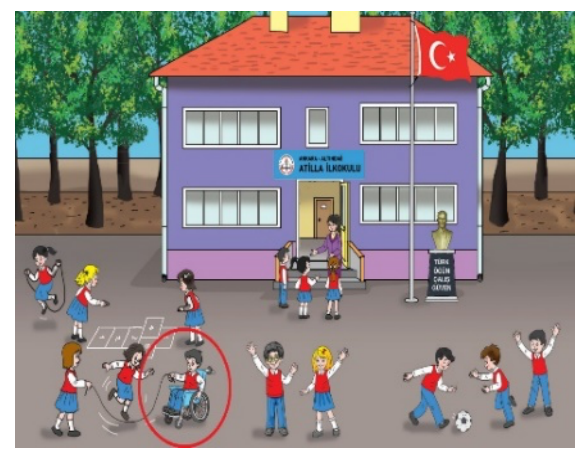

Image 12.

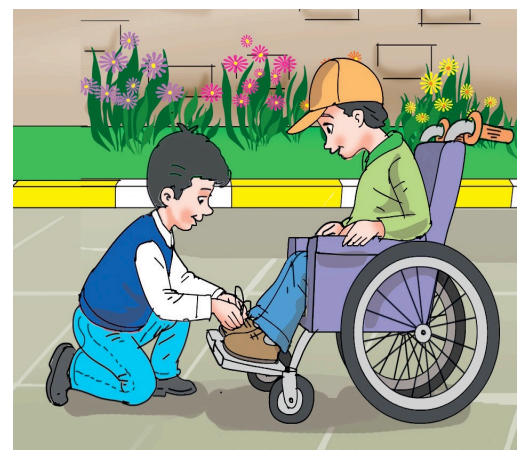

Image 13.

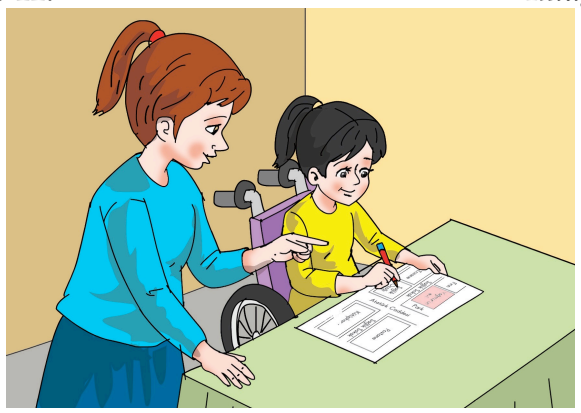

Image 14.

When the distributions of the images in the coursebook were examined, it was observed that the images were presented on the first page of the Life in Our School chapter (Image 12), under the themes of Strengthening My Friendship Bonds (Image 13) and Showing the Location of My House with Sketches (Image 14).

When the pages of the images were examined, it was observed that the images were located on page 10 (Image 12), page 21 (Image 13), and page 56 (Image 14). Apart from these images, no images or texts that were related to individuals with physical disabilities were observed in 
the remaining pages of the book, which was 224 pages long. Furthermore, two of the images that reflected the inclusion students were located in the first chapter of the book, Life in our school, while the other image was located in the Life in Our Home chapter (Image 14). Another feature of Image 14 was that it was the only image that depicted the home atmosphere of an individual with a special disability.

When the image-text relationships were evaluated, it was observed that the only statement "Ali is rather helpful. He helps all of his friends. $\mathrm{He}$ also helps Ahmet when he needs it. Ali treats everyone equally. He respects individual differences. All of Ali's friends love him." was located concerning Image 13 (page 21). No texts that were related to the other images and reflected inclusion students were observed.

\section{Students with Visual Disabilities}

Eyes are one of the sense organs of organisms to sense their environments. They consist of three layers, inner, middle, and outer layers (Özokçu, 2015) and their main function is sight. Briefly, sight is explained as the transfer of images, which arrive at the inner layer of the eyes by passing through outer and middle layers, to the brain via electrical conduction and the interpretation of this information in the brain (Özokçu, 2015). Visual disabilities are conditions where eyes cannot perform the sight function due to damages in the structure of eyes or structural anomalies, which may occur before birth or be due to various reasons experienced after birth (Şafak, 2015). Within the scope of this information, the findings that were obtained from the life studies coursebook were presented below.

Images and texts in the $1^{\text {st }}$ grade Life Studies Coursebook: In the $1^{\text {st }}$ grade life studies coursebook, no findings that reflected the students with visual disabilities were observed.

Images and texts in the $2^{\text {nd }}$ grade Life Studies Coursebook: When the $2^{\text {nd }}$ grade life studies coursebook was examined, it was observed that two images reflected students with visual disabilities. The first one of these images included an image of students who played a musical instrument with other friends under the guidance of a teacher in the classroom envi- 
ronment. In this image, the fact that the students used glasses with black lenses was interpreted as the presence of visual disabilities. In the second image, the student was seen with glasses with black lenses and a cane. These images were located on pages 21 and 22, respectively. Accordingly, it was observed that the students with visual disabilities were represented only on two pages of the book, which was 227 pages long.

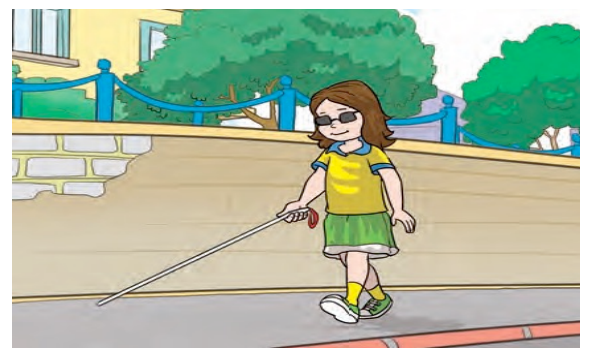

Image 16.

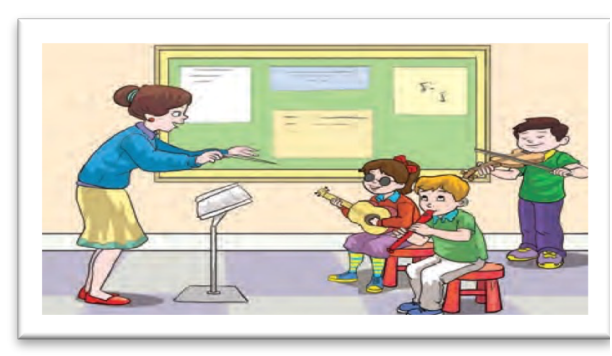

Image 15.

When the image-text relationships were evaluated, it was observed that the statement "Evaluate people not with their physical characteristics but with their good behavior" (p.21), which could be recognized as related to Image 15, was included. Similarly, in another statement, "Examine the images below. Determine the individual differences of students in the images" (p.22), it was asked to compare the other images with Image 16. Except for these two images, no findings that reflected individuals with visual disabilities were observed in the $2^{\text {nd }}$-grade life studies coursebook.

Images and texts in the $3^{\text {rd }}$ grade Life Studies Coursebook: In the $3^{\text {rd }}$ grade life studies coursebook, no findings that reflected the students with visual disabilities were observed.

\section{Students with Hearing Disabilities}

The process of hearing can be defined as the collection of soundwaves that come from the environment in the ears and transferring them to the brain to interpret these data in the brain. Any disruption during this transfer process may result in disabilities in hearing. Individuals with 
hearing disabilities experience problems in transferring the data gathered from the environment to the brain or processing the data that were transferred. In certain situations, this disability can be partially overcome via various aids in collecting/transferring the sounds that are difficult for individuals to collect or transfer. Hearing aids are among these examples. The images that were detected to reflect hearing disabilities in life studies coursebooks were presented below.

Images and texts in the $1^{\text {st }}$ grade Life Studies Coursebook: In the $1^{\text {st }}$ grade life studies coursebook, three images that reflected students with hearing disabilities were observed. All the images depicted the same student. When the images were examined in detail, it was determined that there was a device, which was regarded as a hearing aid, was depicted on the left ear of the blonde girl who stood in the front row. The images were presented on Page 35 (Image 17), page 42 (Image 18), and Page 84 (Image 19). Additionally, all three images were depicted in classroom environments.

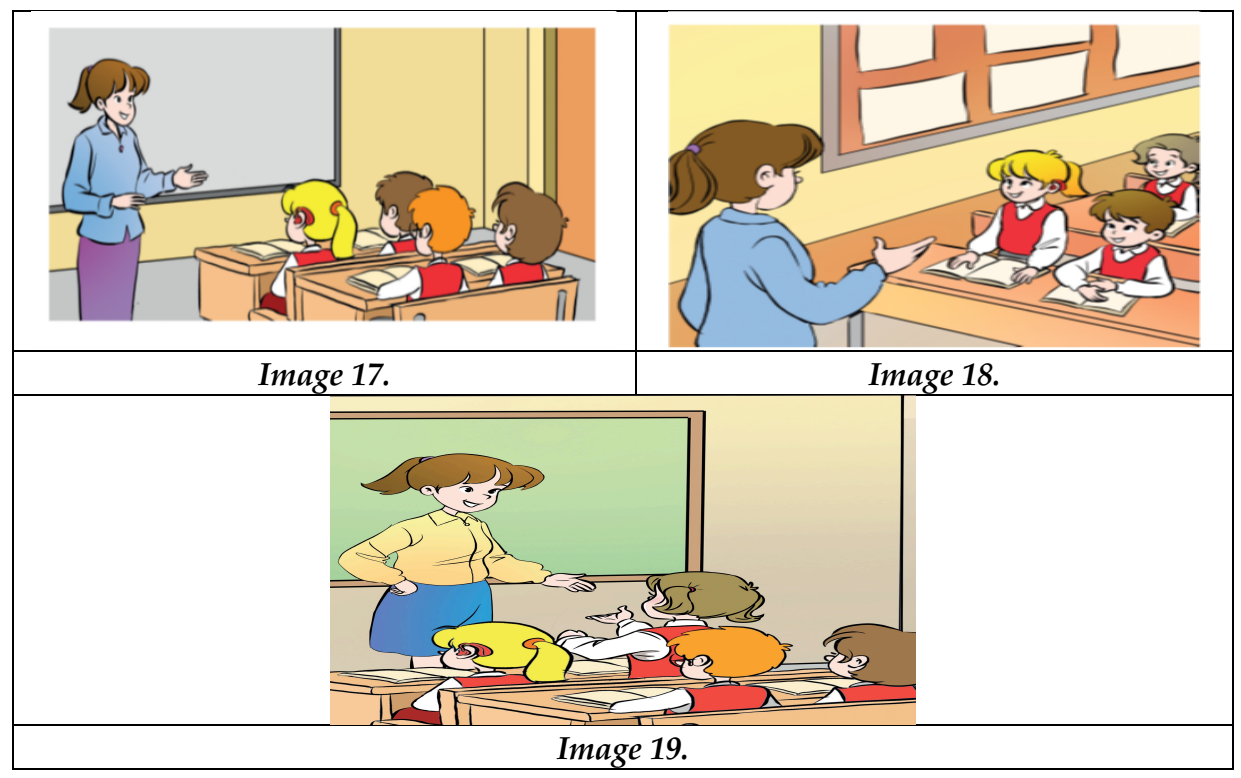


Images and texts in the $2^{\text {nd }}$ grade Life Studies Coursebook: In the $2^{\text {nd }}$ grade life studies coursebook, only one image that reflected students with disabilities (Page 22) was observed. A device, which was a hearing aid, was depicted in the image below.

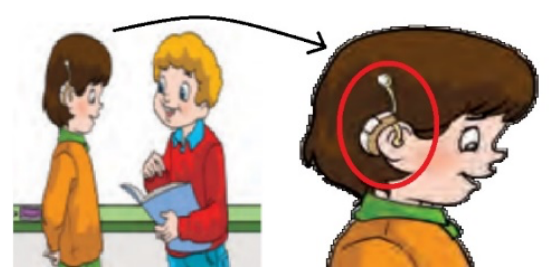

Image 20.

When the texts that were related to the device were examined, two separate statements were observed. The first statement included "Do you have any friends who use glasses, hearing aids or wheelchairs? What do you do to help them?" (p.22), which was followed by "We may have friends who use various devices for health reasons. When necessary, we should help these friends and avoid behaviors that may damage these devices they use" (p.22). The second statement included "We should also accept others as they are. We should not mock people about their differences. We should not even disturb them with our gazes" (p.24).

Images and texts in the $3^{\text {rd }}$ grade Life Studies Coursebook: In the $3^{\text {rd }}$ grade life studies coursebook, no findings that reflected the students with hearing disabilities were observed.

\section{Students with Mental Disabilities}

Although mental disabilities are among the most frequently observed ones in groups that require special education, it was stated that they are not sufficiently recognized by the society (Eripek and Vuran, 2015; Özokçu, 2015). As a result of this, it has been difficult to determine a common definition for mental disabilities as well. According to the definition of the American Association on Intellectual and Developmental Disabilities (AAIDD, 2013), mental disabilities are conditions that demonstrate themselves in both mental functions and adaptive behaviors of individu- 
als and significantly limit daily social and adaptive activities of individuals (Kirk, Gallagher and Coleman, 2015). Factors before, during, or after birth may lead to mental disabilities. The images that were detected to reflect mental disabilities in life studies coursebooks were presented below.

Images and texts in the $1^{\text {st }}$ grade Life Studies Coursebook: In the $1^{\text {st }}$ grade life studies coursebook, no findings that reflected the students with mental disabilities were observed.

Images and texts in the $2^{\text {nd }}$ grade Life Studies Coursebook: In the $2^{\text {nd }}$ grade life studies coursebook, only one image that reflected students with mental disabilities (Page 22) was observed. In this image, two students, who were regarded to have down syndromes, were depicted. Down syndrome is a condition that results from disorders in chromosomes that cause mental disabilities before birth (Özokçu, 2015). Down syndrome is one of the most frequent genetic disorders and it is distinguished by a flattened face (Kirk, Gallagher and Coleman, 2015). When this information was considered, it was observed that two students with down syndrome were depicted in the image of the life studies coursebook, which was presented below (Image 20). Except for this image, no images that depicted a mental disability were observed in the rest of the book. In the text that was related to this image, it was stated that "Our certain friends may learn quickly while others may learn slowly. This is natural. We should not forget that our friends who learn later may also have different skills". Except for this statement, no texts that focused on mental disabilities were observed.

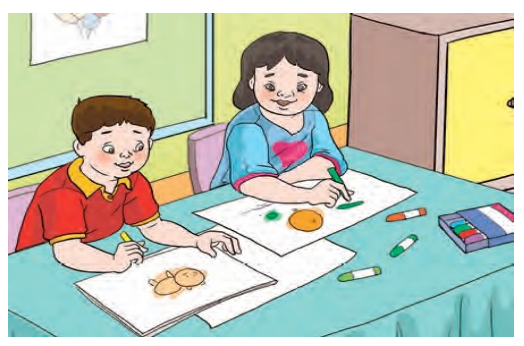

Image 21. 
Images and texts in the $3^{\text {rd }}$ grade Life Studies Coursebook: In the $3^{\text {rd }}$ grade life studies coursebook, no findings that reflected the students with mental disabilities were observed.

In this study, which aimed to investigate conditions that reflected inclusion students in life studies coursebooks, findings that were related to four groups were observed, which covered physical disabilities, mental disabilities, visual disabilities, and hearing disabilities. No findings that reflected other inclusion groups were observed. The information regarding the findings of the study was presented in terms of the groups and their frequencies.

Table 2. Inclusion groups that were reflected as images and their frequencies

\begin{tabular}{lll}
\hline Inclusion groups & Grade Level & f \\
\hline Mental Disability & 2nd Grade & 1 \\
Hearing Disability & 1st and 2nd Grades & 4 \\
Visual Disability & 2nd Grade & 2 \\
Physical Disability & 1st, 2nd, and 3rd Grades & 14 \\
Speech and Language Disability & -- & --- \\
Special Learning Difficulties & --- & --- \\
Individuals with Autism & --- & --- \\
Attention Deficiency and Hyperactivity Disorder & --- & --- \\
\hline
\end{tabular}

Table 3. The frequencies of inclusion groups that were stated in texts

\begin{tabular}{lll}
\hline Grade Level & Number of Pages of Life Studies Coursebook & f \\
\hline 1st Grade & 208 pages & 3 \\
2nd Grade & 227 pages & 5 \\
3rd Grade & 223 pages & 1 \\
Total & 658 Pages & 9 \\
\hline
\end{tabular}

\section{Discussion and Conclusion}

Inclusive education enables students, who demonstrate developmental deficiencies in any field, to receive an education with students who demonstrate normal developments by providing supportive special education services. Inclusive education also provides significant contributions to the social acceptance of individuals' differences in addition to presenting students who have special needs to receive the education they 
deserve (Cheng and Beigi, 2011). However, despite all the efforts, inclusive students require measurements that can raise more awareness on the subject. In general education, the importance of raising awareness on differences is due to affecting the self-respect and learning motivation of students with differences positively. At the same time, recognizing differences in the environment, accepting these differences, and respecting them is important for students who demonstrate normal development. Especially, in primary schools, when it is considered that the classroom material with which the students interact the most is coursebooks, it is observed that coursebooks play significant roles in raising the awareness of students who demonstrate normal development about their classmates with special needs.

In this study, the levels of images and texts that reflected inclusive students in primary school life studies coursebooks were investigated. When the findings were evaluated, out of the eight inclusion groups, which were evaluated within the framework of the study, images, and texts that reflected only physical, visual, hearing, and mental disabilities were observed in the books. No findings that were related to the other groups were observed. When all three books were evaluated (a total of 658 pages), 21 images that reflected inclusion students were observed. When the images that were presented on the remaining pages of the books were considered, this number is rather minimal. In a study conducted by Hodkinson, Ghajarieh, and Salami (2016), coursebooks in Iran and England were examined and it was determined that inclusion students were depicted in a limited way. In this study, the researchers stated that only 21 images out of 4015 images reflected individuals with individual differences. Accordingly, it could be concluded that coursebooks in other countries did not meet the desired level just as they did not in our study.

When the images that described inclusion students in the coursebooks were examined, it was observed that most of the images reflected students with physical disabilities (Image 1-...-14). 14 out of 21 images reflected students with physical disabilities. Here, the point of emphasis is that presenting a single field of disability among the total number can affect students' perceptions toward inclusion. This can create a perception that inclusive students are only those who use wheelchairs. On the 
other hand, the presentation of students with visual disabilities only in 2 images (Image 15 and Image 16), students with hearing disabilities in 4 images (Images 17-...-20), and students with mental disabilities only in 1 image (Image 21) can support the creation of such a wrong perception. When it is considered from this point of view, the focus of coursebooks on physical disabilities compared to other disabilities can lead to the creation of wrong perceptions and attitudes.

When the fields of disabilities were evaluated in terms of grades, it was observed that the 1st-grade life studies coursebook covered students with physical and hearing disabilities. Furthermore, only physical disabilities were presented in the 3rd-grade life studies coursebook while the 2nd-grade life studies coursebook intensively covered physical disabilities in addition to hearing, visual, and mental disabilities, which could be interpreted that the 2nd-grade life studies coursebook was more inclusive compared to others.

On the other hand, when the pages that contained these images and texts were examined, it was observed that the depictions were concentrated on the first chapters of the books. The fact that the depictions were not distributed generally in the books can hinder the possible positive attitude that can develop toward inclusion students throughout the education period. This is not reusing the information that is acquired in the first days of school can cause students to forget them.

When the data that were obtained in the study were examined in detail, it was observed that the characters that depicted inclusion students were generally observed in social environments (Images 1, 3, 8, 9, 11, 12, $15,17,18$ and 19) while they were depicted as individuals who needed help (Images 1, 4, 5, 6, 7, 10, and 13). Furthermore, in certain conditions, it could be criticized that certain values, such as being helpful and respectful, were conveyed through inclusion students. These images can lead to the creation of a perception that inclusion students are "individuals who should be helped", which ignores the complex emotional aspects of inclusion students. More importantly, the creation of this wrong perception can lead to strong impressions that can be held in readers for a lifetime (Hodkinson, Ghajarieh and Salami, 2016; David, 2001).

The roles of coursebooks in increasing the visibility of students with individual differences should not be overlooked. Olson (1989) deter- 
mined that individuals who are at the primary school period can come across 32.000 pages long coursebooks during their educational lives and approximately $75 \%$ of their school time is passed with materials that are presented within coursebooks. Similarly, it was stated that coursebooks were just as the hearts of schools, and the schools of today would not exist if it was not for coursebooks (Westbury, 1990). Thus, the messages of coursebooks are crucial. Accordingly, all the depictions of images that reflected inclusion students in the findings of the study were presented in the school environment, except for two images. One of the images that were out of the school environment was presented in the home environment (Image 14) while the other was depicted in a street (Image 16). However, these types of images are required to be depicted not only in school environments both also in homes, playgrounds, shopping centers, and other parts of life. Only in this way, can the awareness and visibility of students with individual differences be improved. At the same time, this situation can provide numerous benefits. For example, students who experience inadequacy in a field can find themselves in depictions of all aspects of life or characters that accord with them, which can help them gain self-respect, accept themselves as they are, and gain high levels of motivation in every field of life. Similarly, students, who demonstrate normal development and have individuals with disabilities in their families, can accept that these situations are normal and parts of life, which can enable them to view life more positively. Thus, coursebooks also assume the mission of preparing students for life. Crawford (2004) stated that students were social constructs that could inspire socio-cultural order in societies and supported this belief. Therefore, it is an important matter for students to find themselves and their immediate surroundings in coursebooks.

Individual differences are natural circumstances. These natural circumstances show themselves in other creatures as well as in humans. In the wildlife, this is not noticed deeply due to not living for long. However, especially in household pets, those with physical, visual, hearing, or other disabilities can live on with sound care. The awareness of primary school students should be raised that this natural circumstance does not only occur in humans but also it can affect all the creatures. Accordingly, in life studies coursebooks, which are windows that open to the world 
for individuals, the presence of creatures with any type of disability can help students to gain a wider perception about awareness and this natural circumstance.

When all the findings of the study were evaluated, it was observed that the frequency of the texts that were believed to reflect inclusion students was rather low. For example, these texts were included only once in the 1st-grade coursebook, which was 208 pages long, five times in the 2nd-grade coursebook, which was 227 pages long, and three times in the 3 rd-grade coursebook, which was 223 pages long. When all three books were considered, it was determined that only nine pages covered inclusion students in a total of 658 pages. This frequency is rather insufficient in terms of improving the visibility of inclusion.

\section{Recommendations}

Based on the results that were obtained from the findings of the study, the following suggestions were presented.

- In accordance with the essence of inclusive education, coursebooks that contain images and texts should be developed for students with individual differences and special disabilities both to enable their social acceptance and to create a sense of belonging for them.

- In coursebooks, instead of presenting students with special disabilities only in a single group, images that represent all the inclusion groups should be included.

- Students with special disabilities should be depicted not only in schools but also in other fields of life, such as homes, workplaces, and playgrounds. In brief, they should be depicted as pieces of life.

- These students should not be depicted as those who are in need of help but as individuals who have special abilities.

- The coursebooks should certainly cover images and texts, which demonstrate that other creatures may have individual differences as well. 
- Instead of considering inclusive education only in certain chapters of coursebooks, the entirety of coursebooks should be made suitable for inclusive education.

\section{References}

Akcan, E. and İlgar, L. (2016). Kaynaştırma sınıf öğretmenlerinin kaynaştırma konusundaki yeterliliklerinin araştırılması. Hasan Âli Yücel Eğitim Fakültesi Dergisi, 13(2), 27-39.

Anılan, H. and Kayacan, G. (2015). Sınıf öğretmenlerinin gözüyle kaynaştırma eğitimi gerçeği. Bartın University Journal of Faculty of Education, Special issue, 74-90.

Ataman, A., Şapolyo Erol, M., Gevrekçi, M., Çakmak, M., Ercan, L., Yüksel, S. and Çetin, O. (2001). Yabancı dil 4-8, konu alan ders kitabı inceleme klavuzu. Ankara: Nobel Yayın.

Aydın, B. (2019). Gelişimin doğası. Binnur Yeşilyaprak (Ed.), Eğitim psikolojisi, (29-56). in Pegem Akademi.

Candan, D. G. and Ergen. G. (2014). 3. Sınıf Hayat Bilgisi ders kitaplarının temel evrensel değerleri içermesi bakımından incelenmesi. Uşak Üniversitesi Sosyal Bilimler Dergisi, 7(2), 134-161.

Cheng, K. K. Y. and Beigi, A. B. (2011). Addressing students with disabilities in school textbooks. Disability and Society, 26(2), 239-242.

Crawford, K. (2000). Researching the ideological and political role of the history textbook. Issues and methods - 2nd European Conference of Children's Identity and Citizenship in Europe, University of Athens, Greece, May 2000. DOI: 10.18546 / HERJ.01.1.07

Daniel, L. G. and King, D. A. (1997). Impact of inclusion education on academic achievement, student behavior and self-esteem, and parental attitudes. The Journal of Educational Research, 91(2), 67-80.

David, R. G. (2001). Representing the inuit in contemporary British and Canadian juvenile non-fiction. Children's Literature in Education, 32(2), 139-154. doi:10.1023/a:1010338629474

Deniz, E. and Çoban, A. (2019). Kaynaştırma eğitimine ilişkin öğretmen görüşleri. Electronic Journal of Life Sciences, 18(70). 734-761. DOI:10.17755/esosder.448379

Eripek, S. and Vuran, S. (2015). Zihinsel yetersizliği olan çocukların eğitimi. Gönül Akçamete (Ed). Genel eğitim okullarında özel gereksinimi olan öğrenciler ve özel eğitim. (245-282) içinde. Ankara: Kök yay. 
Erkan, A. (1998). Hayat Bilgisi kitaplarında resimleme ve metin ilişkisi. (Yayımlanmamış Yüksek Lisans Tezi). Marmara Üniversitesi Sosyal Bilimler Enstitüsü. İstanbul.

Erol, B. and Kıroğlu, K. (2012). Hayat bilgisi ders kitaplarının dil ve anlatım yönünden değerlendirilmesi. Türkiyat Araştırmaları Dergisi, 32, 155176.

Firat, T. and Koyuncu, İ. (2019). Lise öğrencilerinin özel gereksinimli bireylere yönelik sosyal kabul düzeyleri. Gazi Üniversitesi Ĕ̆itim Fakültesi Dergisi, 39(1), 503-525. DOI: 10.17152 / gefad.431264

Güdük, A. H. and Yılmaz, D. (2019). Kaynaştırma sınıflarındaki normal gelişim gösteren öğrencilerin prososyal davranışlarının incelenmesi. Hacettepe Üniversitesi Ĕ̆itim Fakültesi Dergisi, 36(1), 22-37. (Advance online publication). DOI: 10.16986/HUJE.2019054899

Güleryüz, B. and Özdemir, M. (2015). Sınıf öğretmenlerinin ve sinıf öğretmeni adaylarının kaynaştırma eğitimine ilişkin tutumlarının incelenmesi. Uşak Üniversitesi Sosyal Bilimler Dergisi, 8(3), 53-64.

Gümüş, M. and Tan, Ç. (2015). İlkokul ve ortaokul çağında kaynaştırma eğitimi gören öğrencilere karşı normal gelişim gösteren öğrencilerin tutumlarının incelenmesi. Siirt Üniversitesi Sosyal Bilimler Enstitüsü Dergisi, 4, 90-110.

Hodkinson, A., Ghajarieh, A. and Salami, A. (2016). An analysis of the cultural representation of disability in school textbooks in Iran and England. Education, 3(13). 27-36.

Hwang, Y. and Evans, D. (2011) Attitudes towards inclusion: Gaps between belief and practice. International Journal of Special Education, 26(1). 136-146.

Kapucu, R., Aydoğdu, A. and Benlï, A. (2020). Ortaokul kademesinde kaynaştırma eğitimi gören öğrencilerin uyum becerilerine ilişkin öğrenci öğretmen, veli ve öğrenci görüşleri: Bir durum çalışması. Bartın Üniversitesi Eğitim Araştırmaları Dergisi, 4(1), 34-47.

Karataş, Z. and Arslan, E. (2018). Ortaokulda öğrenim gören zihin engelli kaynaştırma öğrencilerinin normal gelişim gösteren akranları tarafından sosyal kabullerinin incelenmesi. Mehmet Akif Ersoy Üniversitesi Ĕ̆itim Fakültesi Dergisi, 48, 495-513.

Kibria, G. (2005). Inclusion education and the developing countries: The Case of Bangladesh. Journal of the International Association of Special Education, 6(1). 43-47. 
Kirk, S., Gallagher, J. and Coleman, M. R. (2015) Educating exceptional children. (Çev. Ed. Salih Rakap). Nobel yay. 2017.

MEB. (2018). İlkokul Hayat Bilgisi dersi 1, 2 ve 3. simıflar öğretim programı. http://mufredat.meb.gov.tr/Dosyalar/2018122171428547-

HAYAT\%20B\%C4\%B0LG\%C4\%B0S\%C4\%B0\%C3\%96\%C4\%9ERET \%C4\%B0M\%20PROGRAMI.pdf 20.06.2020

Olson, D. R. (1989). On the Language and Authority of Textbooks. S. De Castell, A. Luke, and C. Luke, (Eds.), In Language, Authority and Criticism, 233-244. London: Falmer.

Özokçu, O. (2015). Zihinsel yetersizlik, görme yetersizliği ve işitme yetersizliği. İbrahim H. Diken, (Ed.). İlköğretimde kaynaştırma, (55-88) in. Pegem A.

Öztürk, T. and Özkan, Z. S. (2018). Hayat bilgisi ders kitaplarındaki metin ve görsellerin değerler açısından incelenmesi. Ĕ̆itimde Nitel Araştırmalar Dergisi - Journal of Qualitative Research in Education, 6(1), 172-204.

Pamuk, İ. and Pamuk, A. (2016). Almanya'da Sachunterricht ve Türkiye'de hayat bilgisi ders kitaplarında okulda demokrasi uygulamalarına örnek olarak sınıf başkanı seçimi. Cumhuriyet International Journal of Education-CIJE, 5(2), 67-83.

Patton, M. Q. (2014). Nitel araştırma ve değerlendirme yöntemleri. (M. Bütün ve S. B. Demir, Çev.; 3. baskı). Pegem A. 2014.

Sayed, Y. and Soudien, C. (2005). Decentralisation and the construction of inclusion education policy in South Africa. Compare: A Journal of Comparative and International Education, 35(2), 115-125.

Schwartz, C. and Armony-Sivan, R. (2001). Students' attitudes to the inclusion of people with disabilities in the community. Disability and Society, 16(3), 403-413.

Silvermann, D. (2018). Nitel verileri yorumlama. (E. Dinç, Çev. Edt.; 5. baskı). Pegem A. 2018.

Şafak, P. (2015). Görme yetersizliği olan çocukların eğitimi. Gönül Akçamete (Ed.), Genel eğitim okullarında özel gereksinimi olan öğrenciler ve özel eğitim. (397-440) içinde. Kök yay.

Şahan, G., Uğurlu, M., Özdemir, N. and Nazik, A. (2020). Kaynaştırma eğitimi yapan öğretmenleri ve ailelerin güçlendirilmesi eğitimi. accessed from https://acikerisim.bartin.edu.tr/handle/11772/2246 04/07/2021.

Tural, A., Şahan, G., Işık, A. D., Özdemir, S., Uysal, H. and Yılmaz, O. (2017). Türkiye ve Almanya'daki hayat bilgisi ders kitaplarının resim-metin 
ilişkileri ve kullanımları bakımından karşılaştırılması. Bartın Üniversitesi Ĕ̆itim Fakültesi Dergisi. 6(2), 770-782.

Westbury, I. (1990). Textbooks, textbook publishers, and the quality of schooling. W. Arthur, and D. L. Elliott, (Eds), In Textbooks and Schooling in the United States. 1-22. Chicago.

Yazıcıoğlu, T. and Kargın, T. (2018). Serebral palsili öğrenciler için düzenlenmiş bir okulda gerçekleştirilen kaynaştırma modeline ilişkin paydaş görüşleri. Ankara Üniversitesi Eğitim Bilimleri Fakültesi Özel Ĕ̆itim Dergisi, 19(4), 643-678.

Yılmaz, E. and Batu, E. S. (2016). Farklı branştan ilkokul öğretmenlerinin Bireyselleştirilmiş Eğitim Programı, yasal düzenlemeler ve kaynaştırma uygulamaları hakkındaki görüşleri. Ankara Üniversitesi Ĕ̆itim Bilimleri Fakültesi Özel Ĕ̆itim Dergisi, 17(3), 247-268.

\section{Citation Information}

Akcan, E. (2021). Examination of life studies coursebooks in terms of inclusive education. OPUS- International Journal of Society Reserach, 18(Eğitim Bilimleri Özel Sayıs1), 3948-3974. DOI: 10.26466/opus.899642. 